\title{
Stabilization of Biological Samples in Inorganic Silica Matrices: An Opportunity to Significantly Enhance Infectious Disease Surveillance?
}

\author{
Jason C. Harper* \\ Sandia National Laboratories, Bio-energy and Bio-defense Technologies, Albuquerque New Mexico, USA
}

Submission: October 24, 2017; Published: November 14, 2017

*Corresponding author: Harper JC, Sandia National Laboratories, Bio-energy and Bio-defense Technologies, Albuquerque New Mexico 87185, United States, Email: Jason.Harper@sandia.gov

\section{Opinion}

Development of novel composite materials that stabilize bio-molecular components and living cells within the material matrix, without adversely altering their morphology or activity, continues to be an expanding and challenging field of research. This research is driven by the potential of imparting unique functionalities that are intrinsic to bio-molecules to the new hybrid material. These include selective catalysis of enzymes, specific recognition and binding of antibodies, storage of data by nucleic acids, high-yield production of difficult to synthesize molecules by metabolic pathways, and amplification of weak signals by many orders of magnitude by cell signaling cascades.

Bio-functional materials with these properties would enable significant advances in applications from bio-catalysis, bioelectronics, controlled delivery of therapeutics, tissue engineering, medical diagnostics, advanced prosthetics, environmental and industrial process monitoring, early warning of warfare agents, to energy conversion [1]. Novel materials that stabilize bio-molecules and living cells may also meet a critical need for safe and secure preservation of virus, bacteria and emerging pathogens for disease surveillance. The recent outbreaks of Zika virus in Latin and South America, and Ebola in Western Africa, highlight the challenges associated with detecting and monitoring infectious agents in resource-limited regions.

These challenges include a lack of skilled laboratory staff, the high cost of sophisticated molecular biotechnologies, poor infrastructure (including unreliable power and no cold-chain), limited access to reagents and materials, and the inability to transport samples long distances in a timely manner. Similar challenges are also experienced by far-forward military personal. Safe and secure collection and stabilization of clinical biological samples would allow for accurate identification of the biological, ensuring proper treatment is received for war fighters exposed to a potential infectious agent. Stabilization and evaluation of biological samples from a given region can also ensure that proper training and vaccinations (if available) are received for pathogens specific to the area prior to deploying forces.

In the case of emerging or unknown infectious agents, stabilized clinical samples that allow for transportation from a resource limited region to a modern bio analytical laboratory, facilitating subsequent gold-standard genomic, transcriptomic, proteomic and culture assays, would prove in valuable. Development of a novel bio-molecule stabilization material would thus significantly enhance infectious disease surveillance, early detection, outbreak containment, prediction of emergence/ re-emergence, and identification of new pathogenic agents. Extensive techniques have been developed for bio-molecule and living cell preservation. These generally rely on selective inactivation of sample constituents that degrade the target analyte, or the adsorption, covalent binding, or entrapment of the biological in polymeric materials.

Successful strategies for DNA, RNA, protein and enzyme stabilization are widely reported; however, stabilization of living cells is significantly more challenging [2]. This is due to the more stringent requirements for the encapsulation matrix which must provide a functional bio/nano interface between the cells and the macro environment, protecting the cells from mechanical and chemical stresses, providing access to oxygen and nutrients, and allowing for the expulsion of metabolic wastes [3]. Further, methods used for stabilizing one class of bio-molecules (e.g., DNA and RNA) may be ineffective at stabilizing other classes (e.g., proteins and living cells). While methods exist for stabilizing 
particular classes of bio-molecules, development of a 'universal' bio-sample stabilization matrix that can simultaneously stabilize and preserve DNA, RNA, protein and living cells remains a significant challenge.

Silica materials derived from the sol-gel processes may prove a means to meet this challenge. Advantages of silica for bio-entrapment include the ability of sol-gel based systems to retain water with negligible swelling or shrinkage, chemical and biological inertness, mechanical stability, controlled porosity, resistance to microbial attack, room temperature processing, optical transparency, and the ability to tailor the matrix to provide desired material and chemical properties [4]. Additionally, silica is an archetypical cell-protectant in nature. Diatoms, radiolarians, and sponges have evolved to fix silica onto their cell surfaces, forming exoskeletons that can provide mechanical protection without adversely affecting nutrient and waste exchange [5].

Inorganic silica-based materials have been used to encapsulate and stabilize a wide range of biological materials. Encapsulation of proteins and enzymes in silica sol-gel matrices, with improved stability and comparable activity to enzyme in solution, has been reported. The use of sol-gel films for DNA stabilization, including use for microarray applications and aptamer-based bio-detection, has also been reported [6]. We recently reported the extraction of RNA from cells stabilized in a silica thin film [7]. RNA was intact with little to no degradation and was used for quantitative RNA expression profiling via gene chip analysis to study cellular response under differing environmental conditions and stressors.

Attempts to preserve living cells in inorganic silica materials began in the early 1990s with the pioneering work of Carturan, who encapsulated Saccharomyces cerevisiae in a tetra ethylortho silicate (TEOS) derived silica thin film [8]. Barriers encountered during sol-gel processing resulted in cytotoxicity and low viability. However, sol-gel processing issues can be addressed by reducing the contact time between cells and the sol-gel precursor solution, incorporating ameliorants (e.g., gelatin, polyvinyl alcohol, glycerol) into the silica gel, developing silicates with non-cytotoxic hydrolysis and condensation byproducts (e.g., poly (glyceryl) silicate), utilizing all aqueous precursors (e.g. colloidal silica), depositing silica thin films over cells via exposure to gas phase silica alkoxides, or stabilization of supra molecular assemblies and biological materials in silica thin films by chemical vapor deposition. By exploiting these advances, silica matrices effective at entrapping living cell have been reported [9].

Further, we recently showed that it is possible to remove and recover living cells encapsulated within silica monoliths, with subsequent replication and growth in liquid culture and on solid growth medium $[10,11]$. Despite these many successes, significant obstacles remain in developing a material capable a universally stabilizing all components of any biological sample. Stabilization and preservation of mixed, complex biological samples (i.e., blood, saliva, tissue, field samples) in silica matrices has yet to be reported. Further, extraction of a biological sample from a silica matrix such that the preserved sample is of high quality and compatible with gold-standard genomic, transcriptomic, proteomic, and culture assays remains a significant challenge.

Finally, it is desirable that such chemistry be low cost, simple to use, and have a long shelf-life without refrigeration, facilitating use in low resource settings. Overcoming these obstacles may be possible employing a composite silica matrix. If successful, this novel material may revolutionize infectious disease surveillance, early detection of pathogenic agents, predicting re-emergence, outbreak containment, and identification of new or unknown infectious agents.

\section{Acknowledgement}

Sandia National Laboratories is a multi-mission laboratory managed and operated by National Technology and Engineering Solutions of Sandia, L.L.C., a wholly owned subsidiary of Honeywell International, Inc., for the U.S. Department of Energy's National Nuclear Security Administration under contract DENA-0003525.

\section{References}

1. Wang S, Guo Z (2014) Bio-inspired encapsulation and functionalization of living cells with artificial shells. Colloids Surf B Biointerfaces 113: 483-500.

2. Orive G, Hernández RM, Gascón AR, Calafiore R, Chang TMS, et al. (2004) History, challenges and perspectives of cell microencapsulation. Trends Biotechnol 22(2): 87-92.

3. Murua A, Portero A, Orive G, Hernández RM, de Castro M, et al. (2008) Cell microencapsulation technology: Towards clinical application. J Control Release 132(2): 76-83.

4. Gupta R, Chaudhury NK (2007) Entrapment of bio-molecules in sol-gel matrix for applications in biosensors: Problems and future prospects. Biosens Bioelectron 22(11): 2387-2399.

5. Nassif N, Livage J (2011) From diatoms to silica-based biohybrids. Chem Soc Rev 40(2): 849-859.

6. Saal K, Tatte T, Tulp I, Kink I, Kurg A, et al. (2006) Sol-gel films for DNA microarray applications. Mater Lett 60(15): 1833-1838.

7. Fazal Z, Pelowitz J, Johnson PE, Harper JC, Brinker JC, et al. (2017) Three-dimensional encapsulation of Saccharomyces cerevisiae in silicate matrices creates distinct metabolic states as revealed by gene chip analysis. ACS Nano 11(4): 3560-3575.

8. Carturan G, Campostrini R, Dirè S, Scardi V, de Alteriis EJ (1989) Inorganic gels for immobilization of biocatalysts-Inclusion of invertaseactive whole cells of yeast (Saccharomyces-cerevisiae) into thin-layers of $\mathrm{SiO}_{2}$ gel deposited on glass sheets. J Mol Catal 57(1): L13-L16.

9. Meunier CF, Dandoy P, Su BL (2010) Encapsulation of cells within silica matrixes: Towards a new advance in the conception of living hybrid materials. J Colloid Interface Sci 342(2): 211-224. 
10. Harper IC, Lopez DM, Larkin E, Economides MK, McIntyre SK, et al (2011) Encapsulation of S. cerevisiae in poly (glycerol) silicate derived matrices: Effect of matrix additives and cell metabolic phase on longterm viability and rate of gene expression. Chem Mater 23(10): 25552564.
11. Savage TJ, Dunphy DR, Harbaugh S, Kelley LN, Harper JC, et al. (2015) Influence of silica matrix composition and functional component additives on the bioactivity and viability of encapsulated living cells. ACS Biomater Sci Eng 1(12): 1231-1238.

\section{Your next submission with Juniper Publishers will reach you the below assets}

- Quality Editorial service

- Swift Peer Review

- Reprints availability

- E-prints Service

- Manuscript Podcast for convenient understanding

- Global attainment for your research

- Manuscript accessibility in different formats

( Pdf, E-pub, Full Text, Audio)

- Unceasing customer service

Track the below URL for one-step submission https://juniperpublishers.com/online-submission.php 